\title{
Understanding the challenges to investigating and prosecuting organ trafficking: a comparative analysis of two cases
}

\section{Frederike Ambagtsheer ${ }^{1}$ (D)}

Accepted: 17 May 2021

(c) The Author(s) 2021

\begin{abstract}
The human organ trade is proliferating globally. However, far fewer cases have been prosecuted than would be expected based on estimates of the crime. Research exploring the challenges to investigating and prosecuting organ trafficking cases is practically non-existent. Also no studies exist that explain these challenges utilizing a criminal justice framework. This article aims to explain the legal, institutional and environmental factors that affected the investigation and prosecution of two organ trafficking cases: the Netcare case, exposed in South Africa and the Medicus case, exposed in Kosovo. It analyzes these factors through a comparative, mixed-method design, utilizing a theoretical criminal justice framework. Both cases constituted globally operating criminal networks involving brokers and transplant professionals that colluded in organizing illegal transplants. Both cases contained human trafficking elements, however only the Medicus case was prosecuted as a human trafficking case. Legal uncertainty, a lack of institutional readiness and cross-border collaboration issues hampered investigation and prosecution of the Netcare case. The Medicus case also reported problems during cross-border collaboration, as well as a corrupt environment and institutional barriers, which impeded a successful case outcome. Recommendations to improve enforcement of organ trafficking include improving identification of suspicious transplant activity, strengthening cross-border collaboration and enhancing whistleblower protection laws.
\end{abstract}

Keywords Organ trafficking $\cdot$ Human trafficking $\cdot$ Organ trade $\cdot$ Criminal justice $\cdot$ Law enforcement $\cdot$ Transnational crime

Frederike Ambagtsheer

j.ambagtsheer@erasmusmc.nl

1 Department of Internal Medicine, Erasmus MC, Nephrology \& TransplantationMolewaterplein 40, 3015 GD Rotterdam, The Netherlands 


\section{Introduction}

The global scarcity of human organs has led to an unregulated global organ market (Columb 2020; Moniruzzaman 2019). Although official statistics are lacking, the World Health Organization (WHO) has estimated that approx. 5,000 transplants take place annually using illegally sourced organs (Budiani-Saberi and Delmonico 2008; WHO 2007a, 2007b). Global Financial Integrity ranks the organ trade in the top five of most profitable organized transnational crimes with an estimated annual profit of up to $\$ 1.7$ billion (May 2017).

The WHO first condemned payments for organs in its 1987 Resolution, declaring that 'organs should only be donated freely, without any monetary payment or other reward of monetary value' (WHO 1987). The principle of non-payment for organs has been laid down in various international instruments (Council of Europe 1997; Steering Committee of the Istanbul Summit 2008). Almost all countries prohibit payments for organs (hereafter referred to as 'organ trade') (Amahazion 2016; Council of Europe/United Nations 2009).

In 2000, the United Nations prohibited 'trafficking in human beings for the purpose of organ removal' (THBOR) in its Protocol to Prevent, Suppress and Punish Trafficking in Persons, Especially Women and Children (hereafter, Palermo Protocol) (United Nations 2000). According to this definition, organ trade becomes human trafficking (hereafter, THB) if an individual is threatened, coerced, deceived or otherwise exploited for the removal of his or her organs (United Nations 2000). The Palermo Protocol's definition has received widespread support. The Council of Europe's Convention on Action against Trafficking in Human Beings reproduces the definition as does the European Union's directive on preventing and combating THB (The European Parliament and the Council of the European Union 2011). More than 100 states recognize organ removal as a form of THB in their anti-THB legislation (UNODC 2016).

Despite the worldwide prohibition, far fewer cases have been identified and prosecuted than would be expected based on estimates of the crime. At the time of writing, only 14 convictions involving payments for organs and only one THBOR conviction have been reported to the Case Law Database of the United Nations Office on Drugs and Crime (UNODC 2021). A study by the Organization for Security and cooperation in Europe (OSCE) identified 11 cases that were either charged as THBOR or where the facts appeared to implicate THBOR, even if they were not charged as such (OSCE 2013). Only three of these cases resulted in THBOR convictions (OSCE 2013). The low number of organ trafficking ${ }^{1}$ prosecutions has been attributed to law enforcement's lack of knowledge and awareness of the crime, unwillingness of victims to cooperate, medical codes of secrecy and cross-border collaboration issues (De Jong 2017; Holmes et al. 2016; OSCE 2013; Scheper-Hughes 2004). In the absence of research of prosecuted cases however, knowledge about legal,

\footnotetext{
${ }^{1}$ In this paper, I use 'organ trafficking' as an umbrella term to denote both 'organ trade/payments for organs' and 'THBOR'.
} 
institutional or environmental factors that may facilitate or constrain investigation and prosecution of organ trafficking remains non-existent.

This paper aims to improve our understanding of investigations and prosecutions of organ trafficking through the study of the Netcare -and the Medicus case. The Netcare case is the world's first (and so far, only) reported conviction of a hospital that facilitated over 100 illegal kidney transplants. This case was uncovered in the Republic of South Africa (hereafter South Africa) in 2003 and criminal proceedings occurred until 2012. The Medicus case is the world's first (and so far, only) reported conviction of a group of medical doctors and brokers who were found guilty of organized crime and THBOR. This case was uncovered in the Republic of Kosovo (hereafter Kosovo) in 2008. Both cases contained elements of THB, yet only the Medicus case was charged and prosecuted as a THB case. Why were these cases charged and prosecuted differently, despite their similar modi operandi? This article answers this question utilizing a comparative, mixed-method approach. It explores the legal, institutional and environmental factors that affected the investigation and prosecution of these cases and explains the differences in challenges and outcomes between both cases.

Improving knowledge on organ trafficking prosecutions can enhance our understanding of the hurdles that law enforcement authorities encounter and can offer explanations for why the number of organ trafficking convictions lags far behind prosecutions of other crimes. Furthermore, the acquired information helps to improve our knowledge and understanding on how prosecutions of THBOR compare to prosecutions of other forms of THB. This information allows us to identify challenges that may be specific to investigations of organ trafficking or that may also occur during investigations of other THB cases. The gathered knowledge can support the development of guidelines and recommendations for criminal justice professionals and can help improve investigation and prosecution of organ trafficking.

\section{Organ trade and trafficking}

The human organ trade is driven by an ever-increasing demand for organs. With the ageing of populations and the growth of diabetes and vascular diseases, the number of people with organ failure is growing exponentially. Of all organs, kidneys are highest in demand (Shafran et al. 2014). Approximately $10 \%$ of the world's population suffers from chronic kidney failure and approximately 200,000 patients are registered on kidney transplant wait lists worldwide (ISN 2017). However, only about 65,000 (33\%) patients on these lists receive a kidney annually (Council of Europe 2019). The total number of transplants performed worldwide is estimated to be less than $10 \%$ of the global need (Council of Europe 2019). Average wait times are three to five years and annual mortality rates lie between 15-30\% (Council of Europe 2019).

Despite growing attention for the organ trade, scholarly enquiry into this issue remains scarce (Pascalev et al. 2016). Existing research predominantly describes the detrimental outcomes associated with selling a kidney on the black market 
(Mendoza 2010; Moniruzzaman 2019; Yousaf and Purkayastha 2015).The sale of living donor kidneys is the most commonly reported form of organ trade (WHO 2007b). Only few studies focus on other aspects of organ trafficking. These studies are largely explorative and contain small samples (Columb 2017; Van Balen et al. 2016).

Organ trade and THBOR are separate crimes, yet, organ trade can become human trafficking when an action (recruitment, transportation, transfer, harboring or receipt of persons) followed by the means (threat or use of force or other forms of coercion, of abduction, of fraud, of deception, of the abuse of power or of a position of vulnerability or of the giving or receiving of payments or benefits to achieve the consent of a person having control over another person) for the purpose of organ removal is established (De Jong 2017; United Nations 2000).

Only a few empirical studies shed light on organ trade within a THB context, most of which focus on kidney sales (Columb 2017; Yea 2010; Yousaf and Purkayastha 2015). These studies reveal that kidney sellers are rarely recognized as THB victims, nor do they recognize themselves as such. Kidney sellers commonly actively seek recruiters and brokers themselves. Some become recruiters or brokers after selling their kidney. Sellers -or victims- thus present 'degrees' of THB, meaning that they don't fully conform to the profile of a THB victim. Consequently, they fall through the cracks of anti-THB responses and lack adequate protection. What's more, because most countries prohibit organ sales, kidney sellers who are not identified as THB victims, risk prosecution. Lacking trust and fearing prosecution from authorities, they therefore rarely report abuses (Yea 2010; Yousaf and Purkayastha 2015). According to Columb, the non-recognition of kidney sellers as THB victims and their reluctance to collaborate with law enforcement, explains the low number of prosecuted cases (Columb 2015). Others attribute the low number of prosecutions to the trade's embeddedness in the legal transplant industry, professional oaths of secrecy and the impunity of the medical elite (Capron et al. 2016; Holmes et al. 2016; Scheper-Hughes 2004).

The low number of prosecuted organ trafficking cases hampers research into law enforcement responses to this crime. Only very few studies have been performed that shed light on organ trafficking convictions (Ambagtsheer et al. 2016; De Jong 2017; OSCE 2013). A study conducted by the OSCE provides a rich starting point in exploring criminal justice responses to organ trafficking, highlighting challenges that arise from the trade's transnational dimensions and diverse charging patterns. However, this study did not involve the collecting of information ìn the respective countries and lacked access to official documentation. Furthermore, many of the case proceedings were pending when the report went to press (OSCE 2013). Consequently, this report offers limited information on case outcomes or on legal, institutional, or attitudinal challenges that may have constrained investigation and prosecution. A second study describes three prosecuted cases that were also identified by the OSCE: the Rosenbaum case (uncovered in 2011 in the USA), the Netcare case and the Medicus Clinic case (the latter two being the focus of the underlying study) (Ambagtsheer et al. 2016; De Jong 2017) However, this study lacks a criminal justice framework that explains law 
enforcement's responses to these cases. The next paragraph presents the theoretical framework that conceptualizes the findings of the underlying study.

\section{Theoretical guidance}

\section{Legal environment}

In order to understand why the number of organ trafficking prosecutions remains low, it is important to discuss the role of legal and institutional environments on the implementation and enforcement of new law. Countries have been passing laws against organ trafficking since the WHO first denunciated payments for organs in its 1987 Resolution (WHO 1987). In 1991, the WHO adopted a set of 'Guiding Principles on Human Organ Transplantation' which laid the groundwork for national and international ethical and legal frameworks regulating organ transplants (WHO 1987, 2010). According to these guiding principles, payment for organs should be banned because it is 'likely to take unfair advantage of the poorest and most vulnerable groups, undermines altruistic donation, and leads to profiteering and human trafficking' (WHO 2010). Over 50 countries have adopted laws prohibiting payments for organs (Amahazion 2016; Council of Europe/United Nations 2009). The law against THB(OR), by contrast, is relatively new. Most countries didn't codify the Palermo Protocol's definition of THB into their national legislation until after 2010 and many remain untested (United Nations 2018). Some countries such as the USA, ${ }^{2}$ Venezuela and China have not included 'organ removal' in their anti-THB legislation (UNODC 2016).

\section{Institutional environment}

The passage of new laws is only the beginning of the enforcement process. Most criminal laws do not include measures of accountability, do not specify agencies responsible for fostering implementation and are often unfunded. As a result, many legal changes are seen by enforcement officials as politically motivated mandates that have little to do with the control of crime or maintenance of order (Jenness and Grattet 2005; Manning 2015).

Criminal justice agencies such as police and prosecutors are responsible for developing institutional structures that promote an operational understanding and enforcement of new laws and that overcome institutional resistance (Crank and Langworthy 1992; Farrell et al. 2014). These structures include adopting policies that outline the expected responses to new crimes, training officers regarding new laws, encouraging a shared understanding of the evidence necessary to secure conviction and assigning specialized personnel (Gallagher and Holmes 2008). Yet, studies reveal a history of resistance from law enforcement to new crimes, especially to THB crimes. In the US for example, research has found that law enforcement

\footnotetext{
2 The USA's Federal 2000 Trafficking Victim Protection Act does not recognize the removal of organs as a form of THB. Some US states however, such as Massachusetts, have included the removal of organs in their anti- THB legislation.
} 
agencies have done little to support police and prosecutors in their responses to THB (Farrell et al. 2014; Newton et al. 2008). Institutional deficiencies include a lack of specialization among investigative and prosecutorial personnel, a lack of training and tools and a lack of victim services (Farrell et al. 2014).

New laws are also challenging for prosecutors because the elements of the crime necessary to establish a case are often unclear until tested in court (McPhail and Jenness 2005; Spohn and Horney 1996). Prosecutors are less likely to prosecute cases if they are uncertain about the outcome of obtaining a conviction (Albonetti 1987; Beichner and Spohn 2012). Uncertainty avoidance arises in particular in the case of new crimes and/ or ambiguity of terms (Farrell et al. 2016). The impact of legal uncertainty is particularly significant in the case of THB where key concepts in the definition of the elements of the crime remain vague. For example, states report differences in their interpretation of 'abuse of a position of vulnerability'. There is also no agreed upon definition of 'vulnerability' and 'exploitation' (UNODC 2015). This has led to disparities in how states interpret and prosecute THB cases (Bosma and Rijken 2016; Chuang 2014; Farrell et al. 2016; Newton et al. 2008). In response to an uncertain legal environment, prosecutors have been found to charge individuals engaged in THB with offenses under other statutes (e.g. promoting prostitution, fraud, rape, kidnapping) where the legal elements of the crime are more established and where prosecutors believe there is a greater chance of a conviction (Newton et al 2008). With only four THBOR convictions having been reported worldwide, it can be predicted that these and other factors inhibiting prosecution of THB are particularly likely to be true for THBOR cases.

For both police and prosecutors, structures, rules and routines within organizations are impacted by the local institutional environment (Bromley and Powell 2012; Han amd Nelen 2017; John and Brian 1977; Maguire and Duffee 2015). The institutional environment comprises the cultural and political forces affecting the organization (Garland 2001; Maguire and Duffee 2015). Because the activities of crime control may not affect or reduce the amount of crime in a community, criminal justice officials often must justify their existence in other ways (Maguire and Duffee 2015; Scott 1987). As Crank and Langworthy note, it is difficult to measure the effectiveness of the police in producing the outcomes demanded by their local environment. Instead, police seek to produce legitimacy (Crank and Langworthy 1992). Organizational adaptions to environments serve not only practical or functional reasons, but also serve the need to preserve legitimacy by cultural values or beliefs (Suchman 1995). As a result, criminal justice agencies adopt practices that reflect external stakeholders' values or expectations, even if they maintain their own practices that are decoupled from policies that are declared publically (Han and Nelen 2017).

\section{Methodology}

This study aims to improve our understanding of organ trafficking prosecutions. The following questions are answered: what were the modus operandi of the perpetrators in the Medicus and Netcare cases? How were the cases identified, investigated and prosecuted? What legal, institutional and environmental factors constrained or facilitated prosecution of these cases? How do prosecutions of organ trafficking compare 
to other types of THB cases? In addressing these questions, we rely on concepts from criminal justice theory (legal environment, institutional barriers and environmental factors) to explain and compare law enforcement's responses to each case.

These cases were selected because of their similar modus operandi: both cases involved globally operating criminal networks that recruited patients and donors from different countries and facilitated and conducted illegal transplants in a 'third' country. Both cases contained elements of THB (De Jong 2017). However, the law enforcement responses to these cases strongly differed. Comparing the divergent responses to- and outcomes of both cases provides an opportunity to identify and explain the factors that facilitated or constrained their investigation and prosecution. At the time of writing (2020), this is the first study to shed on light on organ trafficking convictions using a criminal justice framework.

\section{Case study research design}

Utilizing a comparative, mixed-method case study research design (Yin 2018), the research questions are answered through an in-depth exploration of the Netcare case and the Medicus case. The Netcare case (2003-2012) involved a global network of brokers, transplant professionals, recruiters, hospitals, blood banks and interpreters that facilitated over 200 illegal kidney transplants in hospitals across South Africa between 2001 and 2003. The Medicus case involved a global network of brokers, doctors, recruiters and a private medical clinic that facilitated 24 illegal kidney transplants at the Medicus Clinic in Pristina, Kosovo in 2008. The Netcare case was exposed in 2003 and proceedings ended in 2012. The Medicus case was exposed at the end of 2008 and the first verdict was issued in 2013. Since then, there have been appeals and subsequent court decisions, the last being from the Court of Appeals in 2018. At the time of writing, criminal proceedings in Kosovo are still ongoing. Although the identified criminal activities in the Medicus -and Netcare cases covered multiple countries and also led to convictions in Brazil and Israel, this study focuses exclusively on the criminal justice responses in South Africa and Kosovo.

\section{Data sources}

Data was gathered as part of a larger research project, funded by the European Commission, that aimed to increase knowledge, raise awareness and improve responses to THBOR (Ambagtsheer 2017; HOTT Project 2012-2016). The underlying study is based on data that was collected in Durban (South Africa) and in Priština (Kosovo) on the two prosecuted cases during onsite research visits in 2012 and 2013. In-depth interviews were conducted with 20 law enforcement officials, defense attorneys, government officials, transplant professionals and representatives of international organizations. Most interviews took place with law enforcement officials. Some officials were interviewed two to three times. Due to the case's sensitive nature and because case proceedings were ongoing at the time of our visits, several persons refused to be interviewed. Nine respondents did not want to be tape-recorded. During a few interviews, respondents requested to speak offrecord. During the interviews that were not tape-recorded, the research team took notes 
and wrote reports immediately after. The remaining interviews were transcribed verbatim. The respondents are listed in Appendix 1.

The interview process was guided by an information sheet that presented the aims and purpose of the study, listed the contact details of the research team and emphasized that data and names of the respondents would be handled confidentially and anonymously. Each respondent was contacted by e-mail or by phone with requests for an interview and each respondent was given an information sheet prior to the interview. An interview protocol was developed that consisted of a semi-structured list of questions that addressed themes surrounding the investigation and prosecution of the cases. These included: the cases' first signals and indications, obstacles during criminal investigation, evidence-gathering, international collaboration, cooperation of witnesses and victims, the modus operandi of the networks, charges and convictions.

In addition, a vast amount of case materials was collected, namely indictments, charge sheets, extradition requests, judgments, witness -and victim statements, defense letters, closing statements, affidavits and legislation. The case materials are listed in Appendix 2.

\section{Cross case analysis}

The data was analyzed using NVivo-QSR 12 @), a qualitative data analysis software package for coding and analysis. Themes were identified through a multiple-cycle coding strategy and a theoretically informed coding scheme for each case. Preliminary themes were developed based on literature reviews about policing human trafficking and institutional theories related to police response to new crimes. New themes were added that emerged from the interview coding. Next, the two coding schemes were merged into one code structure and a classification for each case was created. Matrix coding queries were then run for themes to examine differences and similarities in modus operandi and law enforcement responses between the two cases, to examine whether the coding was similar between the two cases or if particular codes were more prominent in one of the two cases.

\section{The Netcare case: a South African kidney scandal}

\section{Modus operandi}

In 2001, an Israeli individual, Ilan Perry, entered into an agreement with a private hospital group in South Africa (Netcare Ltd.) involving transplanting Israeli citizens at Netcare's hospitals in Cape Town, Pretoria, Johannesburg and Durban. Perry hired recruiters, interpreters, escorts and other agents who collaborated in bringing recipients from Israel and kidney suppliers ${ }^{3}$ from Israel, Romania and Brazil to

\footnotetext{
3 There is no consensus in the literature on how to depict organ sellers. Different terms are invariably used, including 'victim-donors', 'suppliers' and 'sellers'. In this article, I adopt the terminologies that were used by law enforcement to describe organ buyers and sellers. In the Netcare case kidney sellers were referred to as 'suppliers'. In the Medicus case they were described as 'victim-donors'. For an indepth discussion about terminology of organ sellers, see Gunnarson and Lundin, 2015.
} 
South Africa. Between 2001 and 2003, this network was found to conduct 224 illegal kidney transplants in hospitals across South Africa. Netcare's transplant coordinators helped organize and facilitate the transplant operations. Netcare's surgeons performed the transplants. Approx. 100 transplants were found to have been performed at St. Augustine's Hospital in Durban. At this hospital, Perry had an agreement with a nephrologist, Jeffrey Kallmeyer, establishing that Kallmeyer would be the only referring nephrologist for the Israeli transplant operations. Later, a second broker, Shushan Meir, joined the scheme, who also employed recruiters to supply recipients and kidney suppliers. Thus, with the arrival of Meir, two syndicates coexisted, forming the 'Israeli transplant scheme'.

The prospective kidney recipients paid Perry up to $\$ 120,000$ for a kidney transplant. Perry, in turn, paid Netcare as well as the various involved recruiters, interpreters and other local agents. Kallmeyer received payments directly from Perry. The national health insurance companies of the Israeli recipients reimbursed their transplant costs post-operatively. Until 2008 it was common practice for health insurance companies in Israel to compensate transplants performed abroad, regardless of their illegitimacy (Ambagtsheer 2017; De Jong 2017; Orr 2014; Scheper-Hughes 2011a).

Initially, the kidney suppliers were recruited in Israel and Romania, but soon after Brazilian kidney suppliers were recruited because their kidneys could be obtained at a much lower cost. While the Israeli and Romanian suppliers received approximately $\$ 20,000$ for their kidneys, the Brazilian suppliers were given between $\$ 3,000$ and \$8,000 (Ambagtsheer 2017; De Jong 2017; Scheper-Hughes 2011b). Most kidney suppliers were recruited in Brazil. The recruiters, Gaddy Tauber and Ivan da Silva, also arranged for the suppliers' medical screening, their blood tests and their travel to South Africa. Employees of the South African National Blood Bank crossmatched the pools of recipients and the suppliers until a match was found. Upon arrival in South Africa, local agents took care of practical tasks such as escorting and accommodating the suppliers in apartments, assisting them with their visas and travel bookings and arranging additional medical tests. Prior to the operations, the suppliers and patients signed papers that falsely stated that they were related. Interpreters provided translation services between the recipients, hospital staff and the suppliers. The recipients and suppliers were discharged after their operation and flown back to their home countries.

\section{Start of the investigation}

The case came to the attention of law enforcement in late 2003 when a whistleblower contacted the police. An investigative team was subsequently assigned to the case. The investigators decided to conduct an undercover operation at St. Augustines Hospital. However, before this operation could be completed, the police was 'forced' into action because Meir opened a charge theft against a prospective kidney supplier and his wife. Meir accused them of running away from the hospital before the planned kidney operation, and taking the $\$ 18,000$ with them that Meir had given them prior to the operation. The police subsequently arrested Meir, the (prospective) supplier and his wife and took their statements. 
These statements corroborated the information given by the whistleblower and allowed police and prosecution to apply for a warrant to search St Augustines Hospital, the blood bank and the houses of the accused. The collected evidence included transplant logs, computer files and statements from medical staff, kidney suppliers and recipients. The evidence revealed the dates of the transplants, the names of the recipients and the kidney suppliers, and the names of the surgeons who performed the transplants. It also revealed that cross-matching procedures were performed to match the human leukocyte antigen (typing used to match donors and recipients for transplantation) and blood types of the Israeli kidney patients against multiple prospective kidneys suppliers in order to obtain a transplant match. Furthermore, the evidence showed that a separate transplant scheme was being run parallel to the national transplant procurement scheme. The collected information allowed the police to compare national regulations and procedures with how the Israeli transplant scheme was run and to identify the differences between both procedures. Based on this information, the lead prosecutor concluded that he had a 'prima facie case'. Nonetheless, police and prosecution faced numerous legal and institutional challenges during subsequent stages of the investigation and prosecution.

\section{Legal uncertainty}

First, police and prosecutors reported an uncertain legal environment caused by a lack of appropriate legislation. Because there was no clear prohibition of organ trade and/or THBOR, police and prosecutors could not charge the identified activities as a singular crime. Rather, they relied on a diverse set of provisions laid down in old laws, i.e. the 1983 Human Tissue Act, the 1956 Riotous Assemblies Act and the 1998 Prevention of Organised Crime Act. These acts were however not equipped to cover the identified activities and they contained loopholes. The 1983 Human Tissue Act for example prohibits the sale of organs, but is ambiguous about whether institutions are prohibited from receiving payments that derive from illegal transplants. It also does not prohibit the purchase of organs:

It's ridiculous. They've been talking for years about fixing it [The Human Tissue Act]. They haven't. It's still sitting there. And there's no offense, the only offense on that act is, is you can't sell body parts. The rest you can do virtually anything you like. So we're sitting here with very bad, bad laws. (Prosecutor)

Police and prosecution consequently experienced difficulties with drawing up charges. To overcome legal uncertainty, the state hired a forensic legal consultant who supported the prosecutor with setting up the indictment:

We had to read three sections together that we worked out that it was in fact a charge. Nobody else had ever been able to work it out. And [the prosecutor] and I sitting and just arguing the thing through. I said, 'No but hang on, look at this section, and then look at this section and then look at that section, it is an offence'. And he said, 'You're right. It is an offence'. (Forensic investigative consultant) 
Legal uncertainty is often reported to arise in the case of new and untested laws (Farrell et al. 2014; Grattet and Jenness 2005; Newton et al. 2008). However, in the Netcare case, challenges arose because the existing laws were old and ill-equipped to address the relatively new and unknown trade in living donor kidneys. Thus, in contrast to studies where prosecutors are found to rely on laws that they are more familiar with and that they believe offer greater chances of conviction (Albonetti 1986; Newton et al. 2008), prosecutors in the Netcare case had no choice but to rely on old statutes that did not adequately cover the identified activities and which had mild penalties.

To increase the likelihood of a conviction, a mix of assault, racketeering, money laundering- and human tissue act charges was drawn up from three separate acts, namely: unlawful acquisition, use or supply of tissue, blood, or gamete (under the Human Tissue Act), fraud, forgery, uttering, assault with intent to do grievous bodily harm (under the Riotous Assemblies Act) and acquisition, use or possession of proceeds of unlawful activities (under the Prevention of Organised Crime Act). Because these acts do not regulate living kidney donations, prosecutors also applied a ministerial policy that stipulates that living organ donations between donors and patients who are not genetically related have to be approved by a Ministerial Committee. This violation was added to the charge sheet as it was found that Netcare Ltd. did not follow this procedure for the Israeli transplant scheme. The charges were drawn up against Meir and one other broker (Rod Kimberley), three transplant coordinators (Belinda Rossi, Lindy Dickon and Melanie Azor), four transplant surgeons (John Vivian Robbs, Ariff Haffejee, Neil Godfrey Christopher and Mahadev Naidoo), Jeffrey Kallmeyer, three interpreters, a patient and Netcare Ltd (St. Augustines).

Because South Africa did not have a law prohibiting THB at the time when the Netcare case was exposed, the case was neither regarded nor prosecuted as a trafficking case. Because of the absence of this law and because police and prosecutors had not received training about $\mathrm{THB}(\mathrm{OR})$, they lacked knowledge about what constitutes THB(OR). Their lack of knowledge is illustrated by one of the investigator's depictions of THB:

[T] he people that came out here as donors and even the recipients, none of them came here under duress. In other words, they weren't forced to come here and do the operation. It's one thing to kidnap somebody, bring them over the border, take their kidney out and then take them back across the border. That would clearly be... I don't think human trafficking would have covered anything (Forensic investigative consultant)

This officer's perception of THBOR corresponds with perceptions of other law enforcers who have investigated and prosecuted other types of THB cases such as sex -and labor trafficking, but did not recognize them as such (Farrell et al. 2010; Farrell and Pfeffer 2014). These studies show that, even in countries that have passed anti-THB legislation, police officers conflate THB with (physical) force, kidnapping and coercion and are less likely to qualify cases as THB where victims have consented to the activities involved (Farrell et al. 2010). Other frequently reported challenges in THB cases involve problems surrounding identification of victims, lack of victim cooperation and dealing with behavior of victims that is considered risky 
or criminal, for example because they engage in prostitution or illegal immigration (Farrell et al. 2014). Victims who have engaged in prohibited acts are less likely to be perceived as THB victims by jury or judges. This in turn hampers prosecutors' willingness to pursue trafficking charges and leads them to prosecute trafficking offenders under lesser charges (Newton et al. 2008).

While these challenges are also likely to arise in THBOR cases, for instance when an individual sells his or her kidney, these issues were not reported in the Netcare case. Because a THB(OR) law was absent, there was no uncertainty about whether prosecutors would succeed in prosecuting the Netcare case as a THB case. Furthermore, the donors were not regarded or treated as trafficking victims but as 'suppliers' (Gunnarson and Lundin 2015), whose experiences were, at times, even framed in positive terms. As one of the investigators reiterated:

A lot of them said that it is brilliant, I mean, they were looked after, they were put in a house - they had a place in Durban were they stayed until the operation was done and they could do whatever they wanted. They could go out and visit, and experience the whole place and so on. Their experience was that it was the best holiday they ever had. For them it was awesome. (Investigator)

The kidney suppliers were eventually treated as witnesses. Almost all collaborated by providing statements. Notably, although the suppliers did not self-identify as victims and although they did not report complaints on maltreatment, several coercive elements were found that amount to THB: their passports were taken after entry into South Africa, they did not receive proper information about the post-operative risks and were not given the opportunity to pull out of the procedure in case of doubts. Furthermore, they were discharged from the hospital already two days after their operation which is far sooner than in standardized medical practice. None of them received appropriate follow-up care upon their return to their home countries. The majority reported regret that they had sold their kidney (De Jong 2017).

Would the Netcare case have been prosecuted as a human trafficking crime if South Africa would have had anti-trafficking legislation at the time the case was exposed? On the one hand, awareness of trafficking has been found to be higher in countries that have anti-trafficking legislation and is also greater in law enforcement agencies that have received training (Farrell et al. 2019a; Grubb and Bennett 2012; Irwin, 2017; Renzetti et al. 2015). On the other hand, not all countries that have passed anti-THB legislation, utilize this law to prosecute cases as trafficking, even when there are clear trafficking indicators (Farrell et al. 2014; Newton et al. 2008). For many prosecutors it is easier to investigate and prosecute more established and better -understood offences rather than the complex and resource-intensive crime of THB (Gallagher and Holmes 2008). The question whether the Netcare case would have been prosecuted as THBOR if South Africa would have had an anti-trafficking law at the time, is thus difficult to answer. South Africa codified the Palermo's Protocol's THB definition into its national legislation in 2013, including the removal of organs, a decade after the Netcare case was first exposed. There have neither been reports of THBOR nor prosecutions of THBOR in the country since (UNODC 2021). 


\section{Institutional and environmental constraints}

Institutional structures and policies encouraging enforcement of the identified criminal activities were absent in South Africa at the time when the Netcare case was exposed. For instance, there were no tools, resources or procedures to guide prosecution of trade in living donor kidneys. Police and prosecution also had no prior experience prosecuting organ trafficking cases. They were thus ill-prepared for the investigation and prosecution of the Netcare case. What compounded this challenge was the case's complexity and size. Many of the respondents emphasized the 'complex and voluminous' nature of the investigation. Furthermore, although the evidence indicated that illegal transplantations took place in hospitals across the country, police and prosecutors lacked the capacity and resources to conduct a national investigation:

We had mountains of evidence. We could've charged a hundred people, blood bank people, anesthetists, what have you. But we had to cut it down, and it was quite a job to get it. What was manageable was twelve. If we prosecute 101, that's not going to happen, because we don't have the money to bring them. (Prosecutor and investigator, joint interview)

Because of these issues, and because the available evidence pointed to most illegal transplants taking place at St. Augustines Hospital in Durban, the investigation focused exclusively on the activities that took place there. Yet, also the local police department in Durban suffered from institutional restraints:

We had limited manpower. We joke sometimes to say that overseas you've got one murder case and then you've got thirty detectives investigating one murder. In South Africa you've got one detective investigating thirty murders. (Investigator)

Workshops were organized where prosecution strategies were developed and specialized personnel was assigned to help guide the investigation and prosecution. During these meetings it was decided to focus on prosecuting the 'ringleaders' only, namely, Perry, the four transplant surgeons, two transplant coordinators (Lindy Dickon and Melanie Azor), St. Augustines/Netcare Ltd. and its CEO, Richard Friedland. Yet, police and prosecutors experienced technical issues during the evidencegathering. First of all, the undercover operation at St. Augustines collapsed:

The undercover work didn't give us any results. The reason for that is that our technical side just didn't do a good job to say the least. It didn't work, like the video that sends out signals to the place we had, we didn't receive it, we didn't receive it on our monitors, we didn't see the pictures, we didn't receive the images, we didn't receive the sounds so it was of no use. (Investigator).

This setback compounded police and prosecution's ability to prove that the medical staff knew that the patients and suppliers were unrelated and that the suppliers were being paid. 
During the investigation, successful cross-border collaborations took place with Brazil and Romania where statements with kidney suppliers were taken. However, delays in cross-border collaboration arose with Israel. It lasted four years until Israeli authorities issued statements from the Israeli recipients and suppliers. In addition, the translation of these statements was time-consuming. These delays resulted in several adjournments of the trial proceedings. During this time, Perry was arrested in Germany and prosecutors requested his extradition to South Africa. The lead prosecutor provisionally withdrew the charges against all of the accused, reasoning that the case 'was not ready for trial' in particular because 'the state was still endeavoring to obtain further witnesses through assistance of Interpol'. The withdrawal of the charges, although provisional, was considered a 'weak point in the case' by many of the respondents.

Subsequently, a new prosecutor who was specialized in medical issues, was appointed who decided upon a 'new prosecution strategy'. This prosecutor, amongst others, negotiated with Perry's attorneys in view of utilizing him as a witness. However, these negotiations failed because Germany eventually declined South Africa's extradition request due to the absence of a treaty regulating mutual legal assistance in criminal matters between both countries. Perry was subsequently released from prison and returned to Israel. The prosecutor also negotiated with the accused surgeons and the transplant coordinators on possible non-trial options, however, these negotiations also failed.

In 2011, the accused transplant surgeons and the transplant coordinators submitted a request for a permanent stay of prosecution to the Durban High Court, denying all charges against them, stating that the prosecution was unduly delayed, that they had been unfairly discriminated against, that they had suffered irreparable trial prejudice and that their right to a fair trial had been breached. They emphasized that the lengthy trial proceedings resulted in 'ongoing anxiety, depression, public humiliation, health related problems, a loss of memory and witnesses' (in: the Matter Between Applicants and Deputy Director of Public Prosecutions, Applicants Practice Note, p. 4)). In 2012, the Durban High Court granted the applicants the permanent stay of prosecution, reasoning that:

It is difficult to come to any conclusion other than that there has been an inordinate delay in doing what had to be done to facilitate the beginning of the trial and driving it to its conclusion. What is not apparent is the cause or causes for the delay [...]. I therefore accept that applicants did experience, over a lengthy period of time, various forms of disadvantages including, amongst others, anxiety, social embarrassment, interpersonal and professional stigmatisation and health related problems. (Permanent Stay of Prosecution, Decision, p. 22).

The prosecution has not appealed the court's decision. The remaining accused were convicted, most of whom through plea sentencing agreements. Sentences consisted of monetary fines up to 250.000 Rand and prison sentences of up to 6 years. Netcare Ltd. was sentenced to pay a fine of 4 million Rand coupled with a confiscation order of 3.8 million Rand. 
The evidence collected by law enforcement authorities in Durban assisted law enforcement in Brazil with their prosecutions of Gaddy Tauber, Ivan da Silva and 9 others who were imprisoned on organized crime and human trafficking charges (Scheper-Hughes 2011b). Perry was released in Germany and returned to Israel where he was investigated for tax fraud and released because Israeli transplant laws at the time did not include penalties for brokering overseas transplants (Scheper-Hughes 2011a).

\section{Medicus: organ trafficking in a postwar context}

\section{Modus operandi}

The Medicus Clinic was established in 2004 as a private urology clinic and was owned by a Kosovar urologist, Lutfi Dervishi. In 2005, Dervishi attended a medical conference in Turkey where he expressed his wish to make kidney transplants available for Kosovar citizens. At this conference, Dervishi was connected to Yusuf Sonmez, a Turkish transplant surgeon. By contacting Sonmez, Dervishi tapped into a network of Israeli and Turkish doctors, recruiters and brokers that had been facilitating illegal kidney transplants in hospitals and clinics across Eastern and Central Europe for several years (OSCE 2013; Sanal 2004; ScheperHughes 2004). A vital participant in this network was Zaki Shapira, an Israeli transplant surgeon who collaborated closely with Sonmez and escorted numerous kidney patients to Turkey, Moldova, Russia, USA, South Africa, Kosovo and other places to obtain illegal living donor kidney transplants (Scheper-Hughes 2004). This network recruited patients and donors from abroad and organized the transplants at the Medicus Clinic. Arban Dervishi (the son of Lutfi Dervishi and the director of the clinic), was also closely involved in planning and facilitating the transplants. Although Lutfi Dervishi claims to have applied for a license at the Kosovar Ministry of Health to conduct kidney transplants at Medicus, the clinic was never found to have received such a license.

From March 2008 until November 2008, the network recruited 24 donors in Israel, Turkey, Moldova, Russia, Ukraine, Kazakhstan and Belarus and transported them to Kosovo for the removal of their kidneys at the Medicus clinic. The donors were recruited through internet -and newspaper advertisements. They were promised up to $\$ 30,000$ for their kidney and were matched to 24 recipients, leading to 48 illegal transplant operations. Most recipients were recruited in Israel; a few came from Ukraine, Turkey, Poland, Canada and Germany. Patients paid up to $\$ 108,000$, either in cash at the clinic or through bank wires. As in the Netcare case, Israeli patients receiving transplants at Medicus were able to have their transplant costs reimbursed by their health insurance companies after returning to Israel (Orr 2014; Scheper-Hughes 2011a). 


\section{Human trafficking in Kosovo after the Yugoslav war}

The activities at the Medicus Clinic must be viewed within the context of the postwar vacuum that arose in Kosovo after the 1999 Yugoslav War. After the implosion of the Yugoslav regime, Kosovo became a lawless state. Kosovar Albanians were excluded from health, education, industry, trade and public administration. As a result, illicit economies proliferated to fill the gaps in Kosovo's economy (Proksik 2013, 2017). Organized crime in post-war Kosovo was rife, with trafficking of women for sexual exploitation being the most lucrative illicit activity fueled by the arrival of international peace-keepers (De Wildt 2015; Proksik 2017, 2018). According to The Washington Post, Kosovo was the European capital for THB during that time (Stefanova 2004).

The power vacuum that was left behind after the retreat of the Yugoslav forces, was filled by structures of the Kosovo Liberation Army (KLA). The KLA played a dominant role in the formation of organized criminal networks. Many of these networks obtained political influence, with many of its former leaders acquiring governmental positions. Many continue to hold government positions in Kosovo today (Proksik 2017, 2018). A number of these 'political elites' have been repeatedly accused of either being directly involved in organized crime (including trafficking crimes) or maintaining close relationships with criminal networks (Proksik 2013, 2017). Throughout this study, Lutfi Dervishi was said to form part of this elite.

In 1999, the UN Security Council established the UN Interim Administration Mission in Kosovo (UNMIK). UNMIK is authorized to exercise all legislative and executive authority in Kosovo, which is needed to rebuild the judiciary and the public sector (De Wet 2009; United Nations Security Council 1999). At the beginning of 2008, shortly before Kosovo's Declaration of Independence, the Council of the European Union created a European Union Rule of Law Mission (hereafter, EULEX), which was deployed to substitute UNMIK and to assist authorities in establishing a sustainable and independent rule of law institution (Fierstein 2008). EULEX has also been given power to investigate and prosecute organized crimes, corruption and war crimes (Bajrami 2011). For this reason, a Special Prosecution Office has been deployed in Pristina, which consists of 11 international prosecutors and 10 national prosecutors (Council of the European Union 2018; EULEX Special Prosecution Office 2011). This office initiated the investigation and prosecution of the Medicus case.

\section{Start of the investigation}

Suspicions arose amongst airport authorities throughout 2008 because of Sonmez's regular travels to and from Pristina. Authorities were aware of his background in illegal organ transplants in Turkey. In addition, there were suspicions because foreigners (i.e. the recipients and donors) were arriving in Kosovo and were presenting letters of invitation to customs that explained that the purpose of their visit was to receive treatment for heart diseases. This created suspicion because Kosovo is 
not known for its treatment of heart conditions. In October 2008, a lead investigator was assigned to address these signals. Soon after, this investigator questioned one of the donors at the airport. During questioning, it was determined that this donor had been brought to Kosovo to have his kidney removed and that the recipient of his kidney was still at the Medicus Clinic. Subsequently, a search of the Medicus Clinic took place. During this search, the police identified the recipient and arrested Moshe Harel (an Israeli broker), Arban Dervishi, Lutfi Dervishi and other medical staff. Sonmez reportedly fled the country before the search took place.

The Kosovo Police (KP) collected a vast body of evidence from the Medicus clinic including medical records, patients records and anesthesiology logs. In particular the anesthesiology logs were a vital source of evidence: they outlined the dates and times of the transplants, which doctors were present during surgery, what anesthesia was administered, the names of the recipients and the donor, and the type of surgery that was performed. The evidence was brought to the KP evidence control unit where the KP and the health inspectors discussed the interpretation of the criminal offence and agreed that there was a grounded suspicion of THBOR.

\section{Legal environment}

Under the auspices of the UNMIK and EULEX missions, legislation was adopted in Kosovo in accordance with the UN's and European Union's (EU) legislation, in particular laws against THB and other forms of organized crime. Kosovo is a signatory of the United Nations Convention against Transnational Organized Crime, the Palermo Protocol and the EU directive against THB. Article 139 of the 2004 Kosovo Criminal Code (CCK) contains the legal constituents of the THB definition as stated in the Palermo Protocol, including THBOR. Kosovo also has a 2004 Health Law that prohibits organ transplantations.

We found no uncertainty amongst police and prosecutors in identifying the Medicus case as a trafficking case. Both the lead investigator and lead prosecutor had knowledge and experience in investigating and prosecuting THB cases. As the prosecutor explained:

I saw what it was and I knew what it was when I saw it. I knew it was not just a kidney case or a transplant case, it was organized crime and it was trafficking in humans. I knew the group was using the same routes, the same tactics, the same recruiting. It was identical to what I did in Sarajevo, so I knew it was a trafficking in humans case. It was obvious to me. (Prosecutor, EULEX)

The prosecutor had little difficulty defining elements of the crime, such as the degree of harm needed to constitute THBOR. He also did not doubt that the donors were trafficking victims. The indictment charged Lutfi Dervishi, Arban Dervishi, and the lead-anesthesiologist at Medicus for THBOR and participation in an organized criminal group. International arrest warrants were issued against Sonmez and Harel for the same charges. The indictment stated, amongst others, that the accused:

$[R]$ ecruited numerous persons in foreign countries and transported them to Kosovo for the removal of their organs (kidneys) by means of threat or use of 
force or other forms of coercion, by fraud or deception, by the abuse of power or use of the donor victims positions of vulnerability, or by giving or receiving of payments or benefits to achieve the consent of those persons for the removal of their organs (kidneys), for the purpose of the exploitation of the donor victims (Amended Indictment, p. 11).

The accused and two other anesthesiologists were additionally charged with unlawful exercise of medical activity, abusing official position or authority, grievous bodily harm, fraud and falsifying documents under the CCK. There was also little uncertainty amongst the judges about whether the Medicus case constituted THBOR. What's more, the Basic Court took precedent in defining some trafficking elements in the context of THBOR. By doing so, the court has helped to clarify which organ trade acts can amount to THBOR:

Certain of the donors had serious second thoughts just before the surgery, but were given no opportunity to decline the surgery. Instead, they were wheeled into the operation theatre, tranquilized and operated on, despite their hesitation. They were alone, isolated, did not speak the local language, and had no one to consult as to their best interests. This constitutes coercion. [emphasis added] The donors were told that a kidney removal operation was a simple procedure without any adverse or long-term consequences, which was false and constituted deception. [emphasis added] (Basic Court Decision, p. 115).

These findings contrast with studies of other human trafficking cases that demonstrate that despite the presence of anti-THB laws, police and prosecutors lack knowledge of the crime (Farrell et al. 2015) and find the definition unclear (Farrell et al. 2019a, b). For example, police and prosecutors are reported to struggle with defining certain trafficking elements and report doubt whether victims constitute trafficking victims in the absence of force (Farrell et al. 2019a; Farrell and Pfeffer 2014). Consequently, investigators and prosecutors commonly avoid applying THB laws, and instead apply laws that they are familiar with and of which they believe offer higher likelihood of conviction (Clawson et al. 2008; Farrell et al. 2014; Newton et al. 2008).

While knowledge of THB does not necessarily imply knowledge of THBOR, the Medicus case illustrates that prior knowledge and experience with investigating and prosecuting THB, encourages recognition and prosecution of THBOR cases.

\section{Institutional barriers and environmental constraints}

Despite the strong legal environment and lack of legal uncertainty, various environmental and institutional constraints impeded a successful investigation and prosecution of the Medicus case. Respondents attributed these constraints to the corrupt environment in Kosovo and the 'post-war vacuum' within which agencies operated. For instance, EULEX prosecutors found that local prosecutors were reluctant to pursue prosecution. When EULEX's lead prosecutor arrived in Kosovo in 2010, he found that local authorities had put the case 'under the table'. Moreover, the local judiciary had not issued a warrant for the search of the 
Medicus Clinic. According to the lead prosecutor, the non-issuance of this warrant had been deliberate in order to obstruct the evidence-gathering process:

[T]he Kosovo judges and prosecutors refused to issue valid orders for search and arrest on a number of individuals [...]. [T]hey refused, they testified that they would not do this, because they were off duty and they weren't paid for their duties after hours. And this was their excuse. But it was quite clear due to the evidence that they knew that this clinic was high profile and likely politically connected and they refused to act. And that was a big problem in the case. (Prosecutor, EULEX)

Consequently, the case was described as suffering a 'tortured birth'. The absence of a search warrant impeded the legality of the search and led to uncertainty amongst prosecutors about whether judges would accept the collected evidence.

The corrupt environment also impeded the evidence-gathering from witnesses. Because many of the accused were connected to Kosovo's political elite, witnesses were reluctant to testify. Especially the witnesses who worked at the Medicus Clinic feared losing their jobs if they would testify against their superiors. Also the family of one of the victims received threats by one of the criminal network's members a few days before he was scheduled to testify. Intimidation of victims and witnesses is a commonly reported problem during investigation and prosecution of criminal cases in Kosovo. The country's clan structure and high unemployment rate make it difficult for witnesses to collaborate with law enforcement without seriously endangering themselves or their families or without risks of losing their jobs (OSCE 2006; Stefanova 2004).

Studies generally attribute a lack of prosecutorial willingness to pursuing THB charges to reluctance to changing existing practices or establishing new policies (Farrell et al. 2019a; Grattet and Jenness 2001). In the Medicus case, the lack of willingness to pursue prosecution amongst the local judiciary resulted from a corrupt environment, in particular the accused's connections to Kosovo's elite. Scarce knowledge exists on how corruption affects investigation and prosecution of THBOR and other types of trafficking cases (OSCE 2013; UNODC 2011). The underlying study demonstrates that a corrupt environment can be added to the list of environmental forces that impede investigation and prosecution of THB(OR).

Other reported problems during investigation and prosecution included poor inter-agency collaboration. After the search of the clinic, KP handed the case over to UNMIK, yet, this hand-over occurred shortly before EULEX was meant to take over UNMIK's mandate and collaboration between the two missions was poor. Many of the respondents emphasized the lack of cooperation between both organizations:

It was a very bad handover from UNMIK to EULEX. And then, because EULEX was just starting, there was a lot of confusion about the case. People in custody were released. It was very bad. (Prosecutor, EULEX).

As a result of this poor collaboration, several of the accused left the country. Furthermore, because many victims and witnesses resided outside of Kosovo, 
the investigation relied for a large part on international collaboration. However, collaboration with most countries occurred very slowly, occurred partially or did not occur not all. Some countries do not recognize Kosovo as a sovereign state and therefore did not provide international legal assistance. Other countries did not provide assistance because of confidentiality laws, immunity of witnesses and non-extradition laws. Consequently, many victims and witnesses could not be located and were not available for testimony.

Finally, institutional problems took place within local agencies. One of EULEX's strategies is to work within the local system and thus, the prosecution of the Medicus case took place in local courts. However, these courts were not equipped to provide the technical assistance that was needed to try complex criminal cases such as the Medicus case. As an EULEX prosecutor explained:

The support provided by the local system was dismal. We literally were thrown at the mercy of the local system which we were here trying to improve. It was extremely difficult working in the district court, which had never seen a case like this, had never been involved in a case requiring advanced expert evidence, video link, evidence from several countries. There were language issues, we had uncertified translation, we didn't have simultaneous translation. We had difficulties getting court dates, court hearings were averaging three/ four days a month, which was very poor take up. The environment which we were in was rock bottom. It was like working in a barn. (Prosecutor, EULEX)

These constraints resulted in 'numerous delays in the main trial' (Basic Court Decision, p. 23).

In 2013, the Basic Court found proven that 48 illegal transplant operations took place at the Medicus Clinic. It sentenced Lutfi Dervishi to eight years imprisonment and a $€ 10,000$ fine and Arban Dervishi to seven years and three months in prison and a $€ 10,000$ fine on charges of THBOR and organized crime. It also found Lutfi Dervishi and other medical doctors guilty of unlawful exercise of medical activity. Sokol Hajdini, the lead-anesthesiologist was acquitted from organized crime charges and sentenced to three years in prison. The other accused medical doctors were sentenced to two years in prison. The court also ruled that the identified victim-donors were to be given compensation for psychological and physical damages for the amount of $€ 15.000$.

Since 2013, the case has been subjected toappeals and retrials. In 2015, the Court of Appeals, because a search warrant had not been issued, rendered inadmissible all evidence of the transplants that had been seized at the clinic, including the anesthesiology $\log$ s that proved that 24 illegal transplants took place. In doing so, it modified the Basic Court decision, reducing the number of proven transplants to seven and acquitting some of the defendants due to the warrantless search. It upheld the sentence against Lutfi Dervishi and increased the prison sentences of Arban Dervishi and Hajdini to eight and five years respectively. In 2016, the Supreme Court ruling overturned the original verdict on the basis of procedural irregularities and ordered a retrial. In May 2018 the Basic Court confirmed its earlier convictions, sentencing Lutfi Dervishi to seven years and six months in prison and a 8,000 euros fine, and sentencing Hajdini to a one year imprisonment (Balkaninsight 2018). The 
Court of Appeals ordered a second retrial in November 2018. At the time of writing, proceedings in Kosovo are still ongoing. The defendants have been released on bail, most of whom are claimed to have fled the jurisdiction. EULEX was unable to state whether the identified victims received compensation and remedies.

Israeli authorities were notified about its citizens being involved in the Medicus case after EULEX filed a request for international legal assistance in 2010. They subsequently started an investigation of their own, charging Harel and Shapira with organ brokering under the 2008 Organ Transplant Law. Both plead guilty in 2016 in a plea bargain.

\section{Discussion}

This study reveals that various lessons can be learned from investigating and prosecuting organ trafficking cases. First of all, it is worth noting that many of the reported obstacles reflect challenges in the investigation and prosecution of THB cases more generally. For instance, lengthy investigations, lack of resources, and a lack of experience, knowledge, and awareness of trafficking among law enforcement have also been identified in the investigation and prosecution of labor and sex trafficking cases (Clawson et al. 2008; Farrell et al. 2014; Newton et al. 2008). Nonetheless, the Netcare and Medicus cases constitute landmark cases. Both cases have directed law enforcement attention towards the involvement of medical corporations and medical staff in organ trafficking. Yet, they also demonstrate that legal, environmental and institutional challenges can lead to different outcomes in organ trafficking cases, even when these cases share similar characteristics. Despite law enforcement's best efforts, a weak legal environment, a lack of institutional readiness and environmental constraints constrained prosecution of the Netcare case, resulting in relatively mild penalties of peripheral players and a permanent stay of prosecution of the main accused. Although the Medicus case resulted in high penalties of the core accused, Kosovo's corrupt environment and issues in cross-border collaboration impeded successful outcomes.

Based on prior studies of law enforcement responses to newly defined crimes, in particular trafficking crimes, it was anticipated that uncertainty and reluctance amongst law enforcers would be found in charging and prosecuting organ trafficking (Bosma and Rijken 2016; Chuang 2014; Farrell et al. 2016; Newton et al. 2008). However, findings in the underlying study divert from the existing literature. First of all, the Netcare case illustrates that legal uncertainty also arises in the presence of old laws that are ill-equipped to cover newly arising forms of trade and trafficking such as organ trafficking. The Medicus case demonstrates that prior knowledge and experience with enforcing THB cases promotes enforcement of THBOR, even when anti-THBOR laws are relatively new. Kosovo's anti-THB legislation and the experience of its investigators and prosecutors were however made obsolete by the country's volatile post-conflict environment, its contested sovereignty, and its high prevalence of corruption and organised crime. Notably, the reported challenges in the Medicus case are not specific to organ trafficking cases only but are known to hamper investigation and prosecution of a wide range of serious offences in Kosovo 
(Friesendorf 2010; Proksik 2017, 2018). Nonetheless, this study illustrates the importance of incorporating a weak legal environment, a lack of institutional readiness, corruption, weak statehood and geo-political fragility within the broader criminal justice literature as impediments to prosecution of organ trafficking crimes.

A number of recommendations and future research topics arise from this study. First of all, results reveal the importance of directing law enforcement attention to the involvement of medical corporations and medical staff in facilitating illegal transplants (De Jong and Ambagtsheer 2016; Scheper-Hughes 2004). To support law enforcement and boost identification of suspicious transplant activity, the implementation of reporting mechanisms for staff within medical facilities and other institutions is crucial (Ambagtsheer et al. 2015). Appropriate authorities could be the same institutions that receive information from sex trafficking, domestic violence, and child abuse. Information can include the names of hospitals, clinics, cities, hospital staff, and other individuals who are involved in potentially illegal transplant activities. After analyzing the reported information, the reporting center can submit the information to the national police, who in turn contacts the police forces or liaison officers of the transplant destination country. This national-international reporting method would allow for the information to reach the appropriate authorities and would strengthen the cross-border collaboration and enforcement of the crime (Ambagtsheer et al. 2015; Martin et al. 2016). Previously developed recommendations for reporting mechanisms list the criteria that such mechanisms should fulfil. These include anonymity guarantees for reporters and protection mechanisms for donors and recipients (Ambagtsheer et al. 2015; Danovitch et al. 2013; Martin et al. 2016). In conjunction with establishing reporting tools, enhancing whistleblower protection laws and policies will be needed.

This study's findings also reveal the need for more in-depth research on the crime's organizational structure, its embeddedness in legal industries and on the locations where the crime is prepared and carried out. In particular, a better understanding is needed of the strategies that are used by doctors, brokers and other participants to conceal illegal transplants (Columb 2020; Manzano et al. 2014). Crime scripting and network analysis are helpful methodological tools that can help to deconstruct the stages in the crime commission process, identify which participants are involved in which stage and pinpoint where and how organ trafficking intersects with the medical sector and other legal industries. This information, in turn, can benefit law enforcers in identifying and deterring the crime at an early stage (De Jong 2017; De Vries 2018).

Another recurring theme is the need for strengthened cross-border collaboration during investigations of organ trafficking cases. While cross-border collaboration issues are known to occur during investigations and prosecutions of different types of transnational crimes, the results of this study indicate that successful organ trafficking case outcomes largely depend on cross-border assistance given during evidence-gathering processes and the extradition of accused persons. Establishing bilateral agreements to enhance transfer of evidence and extraditions of suspects is likely to improve case outcomes.

In addition, although more case-based research is needed on the effects of assigning specialized personnel to organ trafficking cases, the Netcare and Medicus cases 
illustrate that employing medical and forensic experts to assist with organ trafficking investigations helps boost positive outcomes. Finally, more comprehensive collection and reporting of data on investigations and prosecutions of organ trafficking is warranted. Although the UNODC's Case Law Database lists organ trafficking prosecutions (UNODC 2021), this list is incomplete (OSCE 2013). In particular knowledge is needed that helps to explain why officially identified organ trafficking activity does not always lead to investigation and prosecution (De Jong 2015). Data collection and reporting is needed to improve our understanding of the prevalence of organ trafficking and to improve evaluation of the efforts that aim to deter it.

While criminal prosecution is important insofar as it represents society's intolerance for particular crimes and may act as a deterrent for future offenses, punishment does little to alleviate the conditions that produce organ trade and trafficking (Columb 2015). In addition, considering the poor enforcement to even the most exploitative forms of organ trade, a punitive response against all commercial dealings in organs may place an unrealistic burden on the criminal justice system. Law enforcers' decisions over which activities to prioritize are often based on chances of securing successful convictions. Prohibition may not then always be accompanied by rigorous enforcement when the police face both the challenges of international investigations and difficulties in proving that an organ was illegally bought (Manzano et al. 2014). Already in its 1980 Report on Decriminalization, the Council of Europe acknowledged that the social costs of.

criminalizing some activities can outweigh the benefits (European Committee on Crime Problems 1980). Hence, it may be more effective to bring only excessive exploitation caused by organ trafficking into the realm of the criminal justice system. Less harmful cases, in turn, could perhaps better be addressed through alternative measures. Examples include decriminalization of organ purchases and sales (Columb 2020) or introducing financial incentives to boost organ donation rates, eliminate transplant wait lists and reduce black market abuses (Elias et al. 2019; Ambagtsheer 2017).

Supplementary Information The online version contains supplementary material available at https://doi. org/10.1007/s12117-021-09421-2.

Acknowledgements The author wishes to thank all respondents for their contributions to this study, in particular the police investigators and prosecutors for hosting and supporting the research team during the study visits. For confidentiality reasons, their names are not disclosed. The author further wishes to thank the HOTT project research team: Susanne Lundin, Jessica Steenbergen, Linde van Balen and Martin Gunnarson for contributing to the data collection processes during the on-site visits. Finally, the author is thankful for Prof. Amy Farrell's valuable advice to this study's analysis and for providing feedback to drafts.

Funding The study was funded by the Prevention of and Fight against Crime Programme of the European Commission Directorate General Home Affairs, under the project, 'Combating trafficking in persons for the purpose of organ removal' (the HOTT project) Grant no. 4000002186, 2012-2016, www.hottp roject.com.

Data availability The anonymized materials listed in the Appendixes are available upon request. 


\section{Declarations}

Ethics All procedures performed in studies involving human participants were in accordance with the ethical standards of the author's home institution Erasmus MC and with the 1964 Helsinki declaration and its later amendments or comparable ethical standards.

Informed consent Informed consent was obtained from all individual participants included in the study.

Conflicts of interest The authors declare that they have no conflicts of interest.

Open Access This article is licensed under a Creative Commons Attribution 4.0 International License, which permits use, sharing, adaptation, distribution and reproduction in any medium or format, as long as you give appropriate credit to the original author(s) and the source, provide a link to the Creative Commons licence, and indicate if changes were made. The images or other third party material in this article are included in the article's Creative Commons licence, unless indicated otherwise in a credit line to the material. If material is not included in the article's Creative Commons licence and your intended use is not permitted by statutory regulation or exceeds the permitted use, you will need to obtain permission directly from the copyright holder. To view a copy of this licence, visit http://creativecommons.org/licen ses/by/4.0/.

\section{References}

Albonetti CA (1986) Criminality, prosecutorial screening, and uncertainty: Toward a theory of discretionary decision making in felony case processings. Criminology 24(4):623-644

Albonetti CA (1987) Prosecutorial discretion: The effects of uncertainty. Law Soc Rev 21(2):291-313

Amahazion FF (2016) Human rights and world culture: The diffusion of legislation against the organ trade. Sociol Spectr 36(3):158-182. https://doi.org/10.1080/02732173.2015.1108887

Ambagtsheer F (2017) OrganTrade. Erasmus University Rotterdam retrieved from www.hottproject.com. Accessed 6th April 2021

Ambagtsheer F, Gunnarson M, De Jong J, Lundin S, van Balen L, Orr Z, Weimar W (2016) Trafficking in human beings for the purpose of organ removal: a case study report. In: Ambagtsheer F, Weimar W (eds) Trafficking in Human Beings for the Purpose of Organ Removal: Results and Recommendations. Pabst, Lengerich, pp 91-116

Ambagtsheer F, van Balen LJ, Duijst-Heesters WLJM, Massey EK, Weimar W (2015) Reporting organ trafficking networks: a survey-based plea to breach the secrecy oath. Am J Transplant 15(7):1759-1767

Bajrami (2011) The Rule of Law in Kosovo: Mission Impossible? BalkanInsight. Retrieved from http:// www.balkaninsight.com/en/article/the-rule-of-law-in-kosovo-mission-impossible. Accessed 7 th March 2020

Balkaninsight (2018) Kosovo Convicts Two in Organ-Trading Trial http://www.balkaninsight.com/en/ article/kosovo-organ-trafficking-medicus-trial-verdict-05-24-2018/1425/3. Accessed 4th July 2020 Balkaninsight

Beichner D, Spohn C (2012) Modeling the effects of victim behavior and moral character on prosecutors' charging decisions in sexual assault cases. Violence Vict 27(1):3

Bosma A, Rijken C (2016) Key Challenges in the Combat of Human Trafficking: Evaluating the EU Trafficking Strategy and EU Trafficking Directive. New Journal of European Criminal Law 7(3):315-330

Bromley P, Powell WW (2012) From smoke and mirrors to walking the talk: Decoupling in the contemporary world. Acad Manag Ann 6(1):483-530

Budiani-Saberi DA, Delmonico FL (2008) Organ trafficking and transplant tourism: a commentary on the global realities. Am J Transplant 8(5):925-929 
Capron AM, Muller E, Ehrlich G, John M, Bienstock RE, McCarren M, Yankov Y (2016) Trafficking in human beings for the purpose of organ removal: stimulating and enhancing partnerships between transplant professionals and law enforcement. Transplant Direct 2(2):e57

Chuang JA (2014) Exploitation creep and the unmaking of human trafficking law. American Journal of International Law 108(4):609-649

Clawson HJ, Dutch N, Lopez S, Tiapula S (2008) Prosecuting human trafficking cases: Lessons learned and promising practices. Retrieved from Washington DC https:/www.ncjrs.gov/App/abstractdb/ AbstractDBDetails.aspx?id=245913. Accessed 2nd October 2019

Columb S (2015) Beneath the organ trade: a critical analysis of the organ trafficking discourse. Crime Law Soc Chang 63(1-2):21-47

Columb S (2017) Excavating the Organ Trade: An Empirical Study of Organ Trading Networks in Cairo. Egypt British Journal of Criminology 57(6):1301-1321

Columb S (2020) Trading Life: Organ Trafficking, Illicit Networks, and Exploitation. Stanford University Press, Stanford

Council of Europe (1997) Additional Protocol to the Convention on Human Rights and Biomedicine concerning Transplantation of Organs and Tissues of Human Origin. Oviedo Convention Retrieved from http://conventions.coe.int/Treaty/en/Treaties/html/186.htm. Accessed 26th February 2020

Council of Europe (2019) Newsletter Transplant. International figures on donation and transplantation. European Directorate for the Quality of Medicines and Healthcare. Council of Europe https://regis ter.edqm.eu/freepub. Accessed 26th February 2020

Council of Europe/United Nations (2009) Trafficking in organs, tissues and cells and trafficking in human beings for the purpose of the removal of organs: Council of Europe and United Nations https://rm. coe.int/16805ad1bb. Accessed 2nd July 2019

Council of the European Union (2018) Council Decision (CFSP) 2018/856 of 8 June 2018 amending Joint Action 2008/124/CFSP on the European Union Rule of Law Mission in Kosovo (EULEX KOSOVO) Official Journal of the European Union, 11.6.2018(L 146/5 )

Crank JP, Langworthy R (1992) Institutional perspective on policing. J Crim 1 \& Criminology 83:338

Danovitch GM, Chapman J, Capron AM, Levin A, Abbud-Filho M, Al Mousawi M, Dittmer I (2013) Organ trafficking and transplant tourism: the role of global professional ethical standards-the 2008 Declaration of Istanbul. Transplantation 95(11):1306-1312

De Jong J (2015) The trade in human organs and human trafficking for the purpose of organ removal. An exploratory study into the involvement of the Netherlands and Europe. Woerden http://hottproject. com/userfiles/Reports/DeJong2015Tradeinhumanorgansandtraffickinginhumanbeingsanexplorat orystudyintotheinvolvementoftheNetherlandsandEurope.pdf. $4^{\text {th }}$ April 2021

De Jong J (2017) Human Trafficking for the Purpose of Organ Removal. Utrecht University, retrieved at www.hottproject.com. Accessed 4th January 2019

De Jong J, Ambagtsheer F (2016) Indicators to Identify Trafficking in Human Beings for the Purpose of Organ Removal. Transplantation Direct 2(2):e56. https://doi.org/10.1097/txd.0000000000000568

De Vries I (2018) Connected to Crime: An Exploration of the Nesting of Labour Trafficking and Exploitation in Legitimate Markets. Br J Criminol 59(1):209-230

De Wet E (2009) The governance of Kosovo: Security Council Resolution 1244 and the establishment and functioning of EULEX. American Journal of International Law 103(1):83-96

De Wildt R (2015) In the wake of war: A cultural criminological perspective on the growth of the sex industry in Kosovo. In: de Jong F, Vervaele JAE, Boone MM, Kelk C, Koenraadt FAMM, Kristen FGH, Rozenblit D, Sikkema E (eds) Overarching views of crime and deviancy - Rethinking the legacy of the Utrecht School. Eleven International Publishing, The Hague, pp 507-526

Elias JJ, Lacetera N, Macis M (2019) Paying for Kidneys? A Randomized Survey and Choice Experiment. Am Econ Rev 109(8):2855-2888

EULEX Special Prosecution Office (2011) Statistical Booklet available at https://www.eulex-kosovo.eu/ docs/justice/SPRK-booklet-28-06-2011.pdf. Accessed 21st November 2018

European Committee on Crime Problems (1980) Report on Decriminalization. Council of Europe. Strasbourg (available on request)

Farrell A, Dank M, de Vries I, Kafafian M, Hughes A, Lockwood S (2019a) Failing victims? Challenges of the police response to human trafficking. Criminol Public Policy 18(3):649-673

Farrell A, Bright K, de Vries I, Pfeffer R, Dank M (2019b) Policing labor trafficking in the United States. Trends in Organized Crime 23:1-21

Farrell A, DeLateur MJ, Owens C, Fahy S (2016) The Prosecution of State-Level Human Trafficking Cases in the United States. Anti-Trafficking Review (6):48 
Farrell A, McDevitt J, Fahy S (2010) Where are all the victims? Criminol Public Policy 9(2):201-233

Farrell A, Owens C, McDevitt J (2014) New laws but few cases: understanding the challenges to the investigation and prosecution of human trafficking cases. Crime Law Soc Chang 61(2):139-168

Farrell A, Pfeffer R (2014) Policing human trafficking: Cultural blinders and organizational barriers. Ann Am Acad Pol Soc Sci 653(1):46-64

Farrell A, Pfeffer R, Bright K (2015) Police perceptions of human trafficking. Journal of Crime and Justice 38(3):315-333

Fierstein D (2008) Kosovo's Declaration of Independence: An incident analysis of legality, policy and future implications. BU Int'1 LJ 26:417

Friesendorf C (2010) The military and law enforcement in peace operations: lessons from Bosnia-Herzegovina and Kosovo https://www.dcaf.ch/sites/default/files/publications/documents/FRIESENDOR FBinder2.pdf. Accessed 7 September 2020

Gallagher A, Holmes P (2008) Developing an Effective Criminal Justice Response to Human Trafficking: Lessons From the Front Line. Int Crim Justice Rev 18(3):318-343. https://doi.org/10.1177/10575 67708320746

Garland D (2001) The culture of control. Oxford University Press, Oxford

Grattet R, Jenness V (2001) Examining the boundaries of hate crime law: Disabilities and the "dilemma of difference". J Crim Law Criminol J (1973-) 91(3):653-698

Grattet R, Jenness V (2005) The reconstitution of law in local settings: Agency discretion, ambiguity, and a surplus of law in the policing of hate crime. Law Soc Rev 39(4):893-942

Grubb D, Bennett K (2012) The readiness of local law enforcement to engage in US anti-trafficking efforts: an assessment of human trafficking training and awareness of local, county, and state law enforcement agencies in the State of Georgia. Police Pract Res 13(6):487-500. https://doi.org/10. $1080 / 15614263.2012 .662815$

Gunnarson M, Lundin S (2015) The Complexities of Victimhood: Insights from the Organ Trade. Somatechnics 5(1):32-51. https://doi.org/10.3366/soma.2015.0146

Han C-R, Nelen H (2017) Decoupling Policy and Practice in the Fight Against Wildlife Smuggling. Br J Criminol 57(1):132-151

Holmes P, Rijken C, D’Orsi S, Hol F, Gallagher A, Greenberg G, Forsythe J (2016) Establishing trafficking in human beings for the purpose of organ removal and improving cross-border collaboration in criminal cases. Transplant Direct 2(2):e58

HOTT Project (2012-2016) Combating trafficking in persons for the purpose of organ removal, www. hottproject.com. Accessed 5th July 2019

Irwin N (2017) Police officer understandings of human trafficking and awareness of anti-trafficking measures. Policing An International Journal of Police Strategies \& Management 40(2):291-305

ISN (2017) International Society of Nephrology. Global Kidney Health Atlas https://www.theisn.org/ global-atlas. Accessed 8 September 2020

Jenness V, Grattet R (2005) The law-in-between: The effects of organizational perviousness on the policing of hate crime. Soc Probl 52(3):337-359

John WM, Brian R (1977) Institutionalized Organizations: Formal Structure as Myth and Ceremony. Am J Sociol 83(2):340-363. https://doi.org/10.1086/226550

Maguire ER, Duffee DE (2015) Criminal justice theory: Explaining the nature and behavior of criminal justice. Routledge, New York

Manning PK (2015) Democratic policing in a changing world. Routledge, New York

Manzano A, Monaghan M, Potrata B, Clayton M (2014) The invisible issue of organ laundering. Transplantation 98(6):600-603

Martin D, Van Assche K, Domínguez-Gil B, López-Fraga M, Budiani-Saberi D, Lavee J, Delmonico F (2016) Prevention of Transnational Transplant-Related Crimes-What More Can be Done? Transplantation 100(8):1776-1784

May C (2017) Transnational Crime in the Developing World Retrieved from Global Financial Integrity https://www.gfintegrity.org/wp-content/uploads/2017/03/Transnational_Crime-final.pdf. Accessed 28th November 2019

McPhail B, Jenness V (2005) To Charge or not to Charge?-That is the question: The pursuit of Strategic Advantage in Prosecutional Decision-Making Surrounding Hate Crime. Journal of Hate Studies 4(1):89

Mendoza RL (2010) Colombia's organ trade: Evidence from Bogota and Medellin. J Public Health 18(4):375-384 
Moniruzzaman M (2019) "The Heavier Selves": Embodied and Subjective Suffering of Organ Sellers in Bangladesh. Ethos 47(2):233-253

Newton PJ, Mulcahy TM, Martin SE (2008) Finding victims of human trafficking. Bethesda: National Opinion Research Center (NORC): Chicago. Document No. 224393. http://citeseerx.ist.psu.edu/ viewdoc/download?doi=10.1.1.218.2468\&rep=rep1\&type=pdf. Accessed 26 May 2021

Orr Z (2014) International norms, local worlds: An ethnographic perspective on organ trafficking in the Israeli context. In: Weimar W, Bos MA, van Busschbach JJV (eds) Ethical, legal, and psychosocial aspects of transplantation: Global issues, local solutions. Pabst Science Publishers, Lengerich, pp $39-49$

OSCE (2006) Review of the Criminal Justice System in Kosovo. The protection of witnesses in the criminal justice system. The administration of justice in minor offences courts. Juveniles in criminal proceedings. Retrieved from Organization for Security and Co-operation in Europe Mission in Kosovo https://www.osce.org/kosovo/23307?download=true. Accessed 5th February 2019

OSCE (2013) Trafficking in human beings for the purpose of organ removal in the OSCE region: analysis and findings. Retrieved from Vienna http://www.osce.org/cthb/10339. Accessed 15 March 2019

Pascalev A, de Jong J, Ambagtsheer F, Lundin S, Ivanovski N, Codreanu C, Weimar W (2016) Trafficking in human beings for the purpose of organ removal: a comprehensive literature review. In: Ambagtsheer F, Weimar W (eds) Trafficking in human beings for the purpose of organ removal. Results and Recommendations, Pabst, Lengerich, pp 15-68

Proksik JJ (2013) Organized crime and the dilemmas of democratic peace-building in Kosovo. International Peacekeeping 20(3):280-298

Proksik JJ (2017) The European Union Rule of Law Mission in Kosovo: a capsized flagship? The many Faces of Crime for Profit and Ways of Tackling it. In: Van Duyne PC, Harvey J, Antonopouolos GA, Von Lampe K (eds) The many faces of Crime for profit and Ways of Tackling it. Wolf Legal Publishers (WLP), Oisterwijk, pp 425-455

Proksik JJ (2018) EULEX and the fight against organised crime in Kosovo: what's the record? Trends in Organized Crime 21(4):401-425

Renzetti CM, Bush A, Castellanos M, Hunt G (2015) Does training make a difference? An evaluation of a specialized human trafficking training module for law enforcement officers. Journal of Crime and Justice 38(3):334-350. https://doi.org/10.1080/0735648x.2014.997913

Sanal A (2004) "Robin Hood" of techno-Turkey or organ trafficking in the state of ethical beings. Cult Med Psychiatry 28(3):281-309

Scheper-Hughes N (2004) Parts unknown undercover ethnography of the organs-trafficking underworld. Ethnography 5(1):29-73

Scheper-Hughes N (2011) The Body of the Terrorist: Blood Libels, Bio-Piracy, and the Spoils of War at the Israeli Forensic Institute. Soc Res 78(3):849-886

Scheper-Hughes N (2011) Mr Tati's holiday and João's safari - Seeing the world through transplant tourism. Body Soc 17(2-3):55-92

Scott WR (1987) The adolescence of institutional theory. Adm Sci Q 32:493-511

Shafran D, Kodish E, Tzakis A (2014) Organ Shortage: The Greatest Challenge Facing Transplant Medicine. World J Surg 38(7):1650-1657. https://doi.org/10.1007/s00268-014-2639-3

Spohn CC, Horney J (1996) The impact of rape law reform on the processing of simple and aggravated rape cases. The Journal of Criminal Law and Criminology (1973-) 86(3):861-884

Steering Committee of the Istanbul Summit (2008) Organ trafficking and transplant tourism and commercialism: the Declaration of Istanbul. The Lancet 372(9632):5-6

Stefanova R (2004) Fighting organized crime in a UN protectorate: difficult, possible, necessary. Southeast European and Black Sea Studies 4(2):257-279

Suchman MC (1995) Managing legitimacy: Strategic and institutional approaches. Acad Manag Rev 20(3):571-610

The European Parliament and the Council of the European Union (2011) Directive 2011/36/EU on preventing and combating trafficking in human beings and protecting its victims, and replacing Council Framework Decision 2002/629/JHA http://eur-lex.europa.eu/legal-content/EN/TXT/? uri=celex:32011L0036. Accessed 21 May 2021

United Nations (2000) Protocol to prevent, suppress and punish trafficking in persons, especially women and children, supplementing the United Nations convention against transnational organized crime. United Nations Office on Drugs and Crime. Vienna. Treaty Series, vol. 2237. https:// treaties.un.org/Pages/ViewDetails.aspx src=TREATY\&mtdsg_no=XVIII-12-a\&chapter $=18$. Accessed 26 May 2021 
United Nations (2018) United Nations Treaty Collection. List of ratifications Protocol to Prevent, Suppress and Punish Trafficking in Persons, Especially Women and Children, supplementing the United Nations Convention against Transnational Organized Crime. Retrieved from https://treat ies.un.org/Pages/ViewDetails.aspx?src=IND\&mtdsg_no=XVIII-12-a\&chapter=18\&lang=en. Accessed 6th July 2018

United Nations, United Nations Security Council, Resolution 1244, S/RES/1244 (1999) https://digit allibrary.un.org/record/274488. Accessed June $2^{\text {nd }}, 2020$

UNODC (2011) The Role of Corruption in Trafficking in Persons. Issue Paper Retrieved from https:// www.unodc.org/documents/human-trafficking/2011/Issue_Paper_-_The_Role_of_Corruption_ in_Trafficking_in_Persons.pdf. Vienna. Austria. Accessed 25th February 2020

UNODC (2015) Issue Paper. The concept of 'exploitation' in the Trafficking in Persons Protocol Retrieved https://www.unodc.org/documents/congress/background-information/Human_Trafficking/UNODC_2015_Issue_Paper_Exploitation.pdf. Vienna. Austria. Accessed 9th July 2018

UNODC (2016) Global Report on Trafficking in Persons. Retrieved https://www.unodc.org/docum ents/data-and-analysis/glotip/2016_Global_Report_on_Trafficking_in_Persons.pdf. last Accessed 1 March 2019

UNODC. (2021). Case Law Database. Available from SHERLOC, from United Nations Office on Drugs and Crime (last accessed 14th February, 2020) http://www.unodc.org/cld/index-sherloccld.jspx

Van Balen LJ, Ambagtsheer F, Ivanovski N, Weimar W (2016) Interviews With Patients Who Traveled From Macedonia/Kosovo, The Netherlands, and Sweden for Paid Kidney Transplantations. Prog Transplant 26(4):328-334. https://doi.org/10.1177/1526924816667951

WHO (1987) World Health Assembly Resolution WHA40.13. Development of guiding principles for human organ transplants https://www.who.int/transplantation/en/WHA40.13.pdf. Accessed 26 May 2021

WHO (2007a) Mapping "Transplant Tourism". Paper presented at the Presentation at World Health Organization's Second Global Consultation on Human Transplantation, Geneva. March 28-30, 2007

WHO (2007b) The state of the international organ trade: a provisional picture based on integration of available information. Bull World Health Organ 85(12):955-962

WHO (2010) World Health Organization Guiding Principles on Human Cell, Tissue and Organ Transplantation, as endorsed by the sixty-third World Health Assembly in May 2010, in Resolution WHA63.22 www.who.int. Accessed 1 August 2019

Yea S (2010) Trafficking in part(s): The commercial kidney market in a Manila slum Philippines. Global Social Policy 10(3):358-376

Yin, R. K. (2018). Case study research and applications: Sage

Yousaf FN, Purkayastha B (2015) 'I am only half alive': Organ trafficking in Pakistan amid interlocking oppressions. Int Sociol 30(6):637-653

Publisher's Note Springer Nature remains neutral with regard to jurisdictional claims in published maps and institutional affiliations. 